Jurnal Pengurusan 58(2020)

https://doi.org/10.17576/pengurusan-2020-58-11

\title{
Investigating Information and Communication Technology (ICT) Usage, Knowledge Sharing and Innovative Behavior among Engineers in Electrical and Electronic MNCs in Malaysia
}

(Menyiasat Penggunaan Teknologi Maklumat dan Perhubungan, Perkongsian Pengetahuan dan Tingkah Laku Inovatif dalam Kalangan Jurutera di Syarikat-syarikat Multinasional Elektrik dan Elektronik di Malaysia)

\author{
Hazril Izwar Ibrahim \\ (School of Management, Universiti Sains Malaysia) \\ Wan Maisara Wan Mohamad \\ (School of Management, Universiti Sains Malaysia) \\ Khairul Anuar Mohammad Shah \\ (School of Management, Universiti Sains Malaysia)
}

\section{ABSTRACT}

Innovative behavior is vital for organizations as competition based on innovation can serve as a basis for sustainable development, especially for multinational companies in the Electrical and Electronic sector in Malaysia. Grounded by the social cognitive theory, this study utilized a research framework examining ICT usage as a predictor of innovative behavior with knowledge sharing (knowledge giving and knowledge receiving) as mediating variables. A total of 309 engineers from multinational companies in the electrical and electronic manufacturing firms in Malaysia participated in this study. By using partial least squares structural equation modeling (PLS-SEM) for analysis, the study revealed that ICT usage has a significant relationship with knowledge receiving. It also found that knowledge receiving played a mediating role in the relationship between ICT usage and innovative behavior. The findings of this study are useful to both academics and practitioners who wish to understand the predictors of innovative behavior so that the innovative behavior can be inculcated among organizational members, and thus, increasing the success of the companies.

Keywords: Innovative behavior; ICT; knowledge sharing.

$A B S T R A K$

Tingkah laku inovatif adalah penting kepada organisasi kerana persaingan yang berasaskan inovasi boleh dijadikan asas untuk pembangunan mampan, terutamanya bagi syarikat-syarikat multinasional dalam sektor elektrik dan elektronik di Malaysia. Berdasarkan teori kognitif sosial, kajian ini menggunakan satu kerangka penyelidikan yang menyatakan kesan penggunaan ICT sebagai pemboleh ubah bebas terhadap tingkah laku inovatif dengan perkongsian pengetahuan (memberi dan menerima ilmu) sebagai pembolehubah perantara. Sejumlah 309 jurutera dari syarikat-syarikat multinasional dalam sektor kejuruteraan elektrik dan elektronik di Malaysia mengambil bahagian dalam kajian ini. Berdasarkan analisis menggunakan pemodelan persamaan struktur (PLS), hasil kajian tersebut mendapati bahawa penggunaan ICT mempunyai hubungan yang signifikan dengan penerimaan pengetahuan. Hasil kajian juga mendapati bahawa menerima pengetahuan memainkan peranan sebagai pembolehubah perantara dalam hubungan antara pemboleh ubah bebas dan tingkah laku yang inovatif, serta memainkan peranan untuk meningkatkan hubungan antara perkongsian pengetahuan (memberi dan menerima pengetahuan) dengan tingkah laku inovatif. Dapatan kajian ini sangat berguna kepada kedua-dua pihak sama ada ahli akademik dan pengurusan syarikat yang ingin mengetahui peramal tingkah laku inovatif supaya tingkah laku inovatif boleh ditingkatkatkan antara ahli-ahli organisasi, dan seterusnya, meningkatkan kejayaan syarikat.

Kata kunci: Tingkah laku inovatif; ICT; perkongsian pengetahuan 


\section{Jurnal Pengurusan 58(2020) \\ https://doi.org/10.17576/pengurusan-2020-58-11}

\section{INTRODUCTION}

Innovation is crucial for all types of organizations and this has been widely accepted among economists, scholars, and practitioners that 'innovation is power' (Lind et al 2018). Researchers believed that competition based on innovation can serve as a basis for sustainable development in post-industrial knowledge economy (Berry 2019; Hansen et al 2020) due to the cost of technology and the growing need for increased flexibility in production (Yu et al 2019; Danquah \& Amankwah-Amoah 2017; Agarwal, Brem \& Dwivwdi 2020). In fact, innovation is critical to the organization to seek new markets, achieving sustainability competitive advantage and determine product viability in the future (Kuncoro \& Suriani 2017). However, according to 2020 Budget Speech by Ministry of Finance, Malaysian economy growth is still in average of 5.1 percent since 2000, and trapped as a middle income nation that hindered from becoming a economy based on productivity and innovation (BNM 2019).

Innovative behavior among the employees is an important factor for the realization of innovation, as it can lead the change to a more improved innovation process either in the production of materials or new ideas (Zhou, Velamuri \& Dauth 2017). Employees can help improve organizational performance and capabilities through their behavior to generate new ideas and make it as building blocks for new and better products, services, and work processes (Michailova \& Minbaeva 2012), and thus positioning themselves as a potential source for creativity and innovation for organizations (Farid, Hakimian \& Ismail 2017). To address innovative behavior among employees, Podrug, Filipovic and Kovac (2017) reveals that ICT use positively influence firm innovation performance and innovativeness.

However, the most important resource an organization can ever have is their employees and their knowledge because each employee has valuable knowledge and it plays a very important role to holistically improve the organizational environment. The importance of knowledge workers has been discussed by previous studies and Annett (2019) highlighted that knowledge workers as an important source to achieve competitive advantage and tackle the risk. Knowledge employees are the most important asset to any organization because their knowledge is able to improve overall workplace environment and personal productivity (Kim et al 2019). With the increasing use of new technology to disseminate knowledge and information among employees, will enhance innovative behaviour among employees and consequently, this will have a positive impact on organizational performance. Knowledge sharing is a fundamental for an organization to make a positive contributions and impact among employees through knowledge application and innovation (Kim \& Park 2017; Pian, Jin \& Lee 2019) .

However, knowledge sharing is not a behavior that occurs naturally (Abdelrahman \& Papamichail 2016). While there is a growing body of literature emphasizing on innovative behavior and knowledge sharing and its importance in the workplace, but very few studies adequately examined these concepts within the context of MNCs, and very rarely in the electrical and electronic manufacturing sector in Malaysia. Thus, this study was conducted to determine whether the ICT usage is able to influence the employee's innovative behavior through knowledge sharing as the mediator. In line with Social Cognitive theory which is the underpinning theory of this research, the key factor all operates as variables that influence the behavior to innovate, can be used by the organization to predict the appropriate decisions related to policies, and regulations, to enhance innovative behavior among their employees.

\section{LITERATURE REVIEW}

\section{KNOWLEDGE SHARING}

While previous studies have been conducted on knowledge sharing and has established the various factors that affect an individual's willingness to share knowledge, such as costs and benefits, incentive systems, extrinsic and intrinsic motivation, organization climate, and management championship (Lin 2007a, 2007b; Suppiah \& Sandhu 2011; Wasko \& Faraj 2005), however, there is a lack of emphasis on knowledge sharing in the context of innovative behavior as a consequence of knowledge sharing influenced by ICT usage. Donate and Guadamillas (2011) and Donate et al (2017) argue that knowledge sharing is a major concern because of the recognition of the value of organizational learning in knowledge creation and innovation within an organization. In line with this, the literature reviews in this study attempt to lay the foundation for the relationship between the variables, thus, providing a basis for the research framework.

Knowledge sharing can be defined as the culture of social interaction, including the exchange and sharing of knowledge, experience, and expertise among employees through the entire department or organization. Knowledge sharing is confirmed as one of the important aspects of knowledge management (Singh, Chadwani \& Kumar 2018) and the key to the success of knowledge management is dependent on knowledge sharing (Wang \& Noe 2010; Obeidat, Al-Suradi \& Tarhini 2016). There are various factors that influence the behavior of sharing knowledge, 


\section{Jurnal Pengurusan 58(2020) \\ https://doi.org/10.17576/pengurusan-2020-58-11}

such as communication, information systems, rewards, organization structure, job satisfaction, organizational culture, organizational climate, leadership, the norm of reciprocity and trust, and intrinsic-extrinsic, and motivation (Ali, Paris \& Gunasekaran 2019; Chmielecki 2017; Goh et al. 2020; Kaabi, Elanain, \& Ajmal 2018; Kucharska \& Bedford 2019; Razmerita, Kirchner \& Nielson 2016). All the information and knowledge sharing is entirely dependent on the provider and supplier knowledge, not knowledge recipient (Hussein et al. 2016). While the twoway information sharing is different, it involves the exchange of information and knowledge between individuals and other individuals through giving and receiving knowledge. It is also known as collecting and donating knowledge process (Belle \& Oliveira 2018; Hooff \& Ridder 2004). This perspective was shared and demonstrated by other researchers such as Karkoulian, Harake and Messarra (2010); Lin (2007b); and Tohidinia and Mosakhani (2010).

Knowledge sharing process consist of two processes which are bringing (or 'donating') and getting (or collecting) knowledge (Hooff \& Ridder 2004; Yadav, Choudhary \& Jain 2019; Nguyen et al. 2020). Hooff and Ridder (2004) has combined both these perspectives and named them as 'knowledge donating' and 'knowledge collecting'. 'Knowledge donating' involves communicating to other individuals with regard to the personal capital available to an individual. While 'knowledge collecting' involves negotiations between an individual with other individuals to share and gain knowledge of their intellectual capital. Both of these dimensions have different properties and have dynamic considerations. According to Hooff and Ridder (2004), both of these dimensions have been accepted and used by various studies.

In the context of this study, knowledge sharing refers to the exchange of information between individuals through active knowledge donating and collecting knowledge. By applying this concept, this study highlights the term of knowledge donating as knowledge giving and collecting knowledge as receiving knowledge as it is more concise and easier to understand because the term is often applied widely, especially in the Malaysian context. The concept of sharing knowledge through bidirectionally (two ways) is chosen for the current study because it is more appropriate in an organizational environment such as manufacturing firms, as it involves various structures, parts, and department, require employees to exchange views and information among each other. Otherwise, one-way knowledge sharing approach may be only appropriate for adaptation in the study involving a specialist who delivers information to the individual needs and does not require advice or other information from that individual. Therefore, the 'giving knowledge' and 'receiving knowledge' is used in this study is derived from the concept of 'knowledge donating' and 'knowledge collecting' by Hooff and Ridder (2004).

\section{ICT USAGE}

Information and Communication Technology (ICT) as 'web-base technologies' is approved expended the quantity, quality, and density of knowledge (Khawaja 2017). ICT is recognized as the most prominent tool for facilitating the knowledge sharing intention and recognized as a platform and an umbrella term that includes computer hardware and software, digital broadcast and telecommunications technologies as well as digital information repositories online or offline and this includes contemporary social networking aspect for online file sharing system (Khawaja 2017). This is because ICTs is able to provide a wide range of tools to support knowledge sharing processes (Alavi \& Leidner 2001). The use of ICTs in the organization might be in a combination of both long-standing tools, such as e-mails, telephones, teleconferencing, intranets, group decision support systems, or databases. It also consists of newer interactive social media tools, such as wikis, blogs, online communities, social networking sites, and micro-blogging.

From an organizational perspective, the employee's task is typically complicated and may involve multiple subprocesses (Yuan et al. 2013), especially in an established organization with a huge and multiple levels such as the manufacturing firms. Employees are also involved in assimilating the knowledge, and these requires both the search and shared processes that by using different tools to satisfy their work needs. As a result, the task complexity, along with the availability of different types of ICTs, calls for more extensive research on media multiplicity (Haythornthwaite \& Wellman 1998; Usman, Ahmad \& Burgoyne 2019), explaining how ICTs can be used in combination to support communication and knowledge sharing needs. Previous studies have shown that the usage of ICTs in organizations can be used by combining the different tools to serve communication's need for knowledge sharing (Abdelrahman, Papamichail \& Wood-Harper 2016; Amin et al 2018; \& Jasimuddin \& Perdikis 2019).

However, there is also a controversy about a role of ICT with regard to knowledge sharing, when authors stress and argued the potential benefits of ICTs in knowledge management (e.g Hachicha \& Mezghani 2018; Ibrahim \& Jebur 2019) as ICTs is also widely criticized for their limitation in facilitating knowledge process in organization (Madhavaram et al 2017). Apart from that, the advocates of ICT as a driver for knowledge management approach are also blamed because it only focuses on the explicit side of knowledge, while ignoring the tacit side (Khanam et al 


\section{Jurnal Pengurusan 58(2020) \\ https://doi.org/10.17576/pengurusan-2020-58-11}

2017; Panir, Xiolin \& Zijun 2019). However, without no doubt, Kaabi et al (2018) and Maimone (2018) approved that technology is accepted for learning and knowledge, and very dominant in knowledge management area.

\section{UNDERLYING THEORY}

According to Bandura (1971), Social Cognitive Theory (SCT) provides guidance, understanding, and prediction of human behavior to change in line with changes in personal and environment factors. SCT is based on assumptions of human behavior, where individual behavior is influenced by the interaction of personal, social, and environmental.

SCT also explain that individual abilities and individual factors have a high possibility of receiving influence from environmental factors (Bandura 2001; Stajkovic et al 2018). Bandura (1971) has classified environmental factors into two categories, namely, social and physical. The social environment is identified as a socio-environment relationship, such as the relationship that exists between workers and management, relations between colleagues, relationships between family members, and the organization policy. While the physical environment, refers to the physical factors existing in the surroundings of an individual such as buildings, infrastructure, temperature conditions, and equipment. He also explained that the interaction exists between the environment and individual factors, including human beliefs and cognitive capabilities, individual factors will determine the condition of the environment, and vice versa, the environment can also change and determine the behavior of an individual. In the context of the organization, organizational innovative climate factors, namely support for innovation and organizational culture can be classified as environmental factors that affect the organization and impact of the employees in the organization (Bandura 2001).

SCT is a theory that is the most suitable as the underlying theory in this study because it comprehensively covers the research framework. The interaction between environmental and personal factors can change the behavior of individuals as theorized in SCT could be explained by the comprehensive coverage on the relationship between ICT usage, knowledge sharing and innovative behavior. The study proposes that the behavior of knowledge sharing through giving and receiving knowledge of employees will be affected by ICT usage, which in turn affects individual innovative behavior (Bandura 1989; Phung, Hawryszkiewycz \& Binsawad 2017). Therefore, SCT is an ideal theory to explain the research framework of the current study.

\section{THE RELATIONSHIP BETWEEN ICT USAGE, KNOWLEDGE SHARING AND INNOVATIVE BEHAVIOR}

\section{ICT USAGE AND KNOWLEDG SHARING}

According to Hooff et al. (2003), the use of ICT directly facilitates easier exchanges and help create connectivity that promotes knowledge sharing. Their research on knowledge sharing in knowledge communities has proven by the result that ICT's most important contribution to knowledge sharing in communities, consist of realization of shared information base and facilitating communication independent of time and place as connectivity. Lin (2007b) in his empirical study of knowledge sharing and firm capability found that there is a positive relationship between ICT use and knowledge collecting (knowledge taking), but not significant in knowledge donating (knowledge giving). In other words, the analytical result has proved that most of the respondent agreed that the use of various ICT tools helps them receiving the knowledge. Consistent with this, Cheng, Ho and Lau (2009) in their study on knowledge sharing in academic institutions argued that it is essential to create an environment which is peopleoriented, in order to promote knowledge sharing activity, rather than technological-oriented. Although technology plays important roles in minimizing the barriers and increase the propensity to share knowledge, they suggested that knowledge sharing is still people-process. Based on the previous literature and assumptions of this study, the following hypotheses were formulated:

$\mathrm{H}_{1} \quad$ ICT use has a positive effect on knowledge giving.

$\mathrm{H}_{2} \quad$ ICT use has a positive effect on knowledge receiving.

\section{KNOWLEDGE SHARNG AND INNOVATIVE BEHAVIOR}

Chen, Huang and Hsiao (2010) in their study found that knowledge management (creation and sharing knowledge) is positively related to innovativeness. A study conducted by Yu, Yu-Fang and Yu-Cheh (2013) shows that knowledge sharing among employees will be able to increase individual innovative behavior and their ability to innovate. More workers doing knowledge sharing, more knowledge can be internalized. Mura et al. (2013) proved that there is a positive role by behaviors in sharing information to give effect to the sharing of innovation. It can be 


\section{Jurnal Pengurusan 58(2020) \\ https://doi.org/10.17576/pengurusan-2020-58-11}

seen through the propensity and capacity to promote and implement new ideas within the organization. In other words, knowledge sharing behavior has a positive role to give the impression of sharing innovation among employees. Indirectly, this sharing of knowledge can create a positive relationship to the existence of innovative behavior. Therefore, this study empirically investigates the direct linkage between knowledge sharing (giving and receiving) and innovative behavior. Hypothesis three and four is as follows:

$\mathrm{H}_{3} \quad$ Knowledge giving has a positive effect on innovative behavior.

$\mathrm{H}_{4} \quad$ Knowledge receiving has a positive effect on innovative behavior.

\section{MEDITING EFFECT OF KNOWLEDGE SHARING BETWEEN ICT USAGE AND INNOVATIVE BEHAVIOR}

According to Arvanitis, Loukis and Diamantopoulou (2013), little attention has been given to possible direct effects of ICT to enhance innovation. They suggest that ICT enabler is more efficient when cooperation with innovative employees since the exchange of knowledge and information is easy and will go beyond the normal boundaries. ICT is seen as a tool that is able to increase knowledge sharing and communication process in MNCs, automatically realized of new ideas and innovation implementation. Thus, this study expects to explore this relationship in E\&E MNCs in Malaysia, and hypothesis five and six is proposed as follows:

$\mathrm{H}_{5} \quad$ Knowledge giving mediates the relationship between ICT usage and innovative behavior.

$\mathrm{H}_{6} \quad$ Knowledge receiving mediates the relationship between ICT usage and innovative behavior.

\section{METHODOLOGY}

The target population of this research is engineer employed by MNCs in the Malaysian electrical and electronic manufacturing sector. Thus, the study utilized purposive sampling technique for data collection. The main criteria are that they are emploted as engineers and have subordinates to engage in knowledge sharing activities. The study focuses on engineers because they are in the best position that can provide reliable information to the researcher in studying knowledge sharing and innovative behavior in organizations, because their jobs are specifically related to innovativeness and sophisticated knowledge that requires sharing information with other employees. The survey method of self-administered questionnaire approach have been recognized as the most appropriate method for this study. This study adopts postal mail and 'drop-off and collect' for data collection. The combination of these techniques is based on the ability of these techniques to have higher response rates (Ahmad, Husin \& Saad 2017; Couper 2017). This study is a cross-sectional study which relies on the engineer's responses to the questionnaires. The questionnaires were distributed and collected from the multinational companies in electrical and electronic sector in Malaysia, listed in the Federation of Malaysian Manufacturers Electrical and Electronic Directory 2016. A total of 1550 questionnaires was distributed and 550 questionnaires were collected. However, only 309 questionnaires were found to be useful. Before analyzing the data, the data were screened for missing data, outliers, normality, and common method variance. There are no missing data responses found, and no outliers were deleted because they were not influential responses. The examination of the skewness and kurtosis of the variable revealed that the data were not extremely non-normal, indicating that there were no issues regarding to normality.

\section{MEASUREMENT OF VARIABLES}

Dependent Variable Innovative behavior. The measures are adopted from Janssen (2000) scale for individual innovative behavior in the workplace with nine items scales (Cronbach's alfa $=0.95$ ). The nine items have divided into three stages of innovation, which is idea generation (three items), idea promotion (three items), and idea realization (three items). All the items are measured with the questions "With what frequency do you engage in the behaviors listed below?", by five points behavioural frequency range from (1) for 'Never', (2) for 'Almost Never', (3) for 'Sometimes', (4) for 'Often', and (5) for 'Very Often'. The details of the items have been explained in TABLE 1.

TABLE 1. Measurement of innovative behavior

\begin{tabular}{ll}
\hline No. & Innovative Behavior Items \\
\hline 1 & Idea Generation \\
& a. Creating new ideas for difficult issues.
\end{tabular}




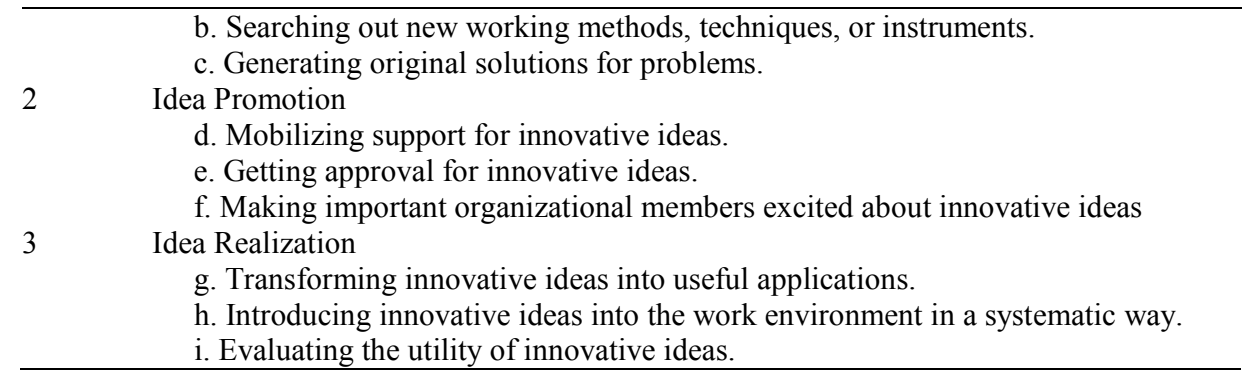

Independent Variable ICT Usage. The application of ICT is closely related to knowledge sharing as it enables and effects employees' effectiveness and innovativeness (Bock et al. 2005; Lin 2007a; Taylor \& Wright 2004; Wasko \& Faraj 2005). In this study, ICT usage construct was measured by four items adopted from (Lin 2007b), with Cronbach's alpha $=0.83$. The purpose is to define the degree of employee's ICT usability and capability towards knowledge sharing. In the questionnaire, the measure applies a five-point scale ranges from ' $1=$ Strongly Disagree' to ' $5=$ Strongly Agree'. The summary of the items measure is shown in TABLE 2.

TABLE 2. Measurement of ICT usage

\begin{tabular}{ll}
\hline No. & ICT Usage Items \\
\hline 1 & Employees make extensive use of electronic stage (such as online databases) to access knowledge. \\
2 & $\begin{array}{l}\text { Employees use knowledge networks (such as groupware, intranet, virtual communities) to communicate with } \\
\text { colleagues. }\end{array}$ \\
3 & My company uses technology that allows employees to share knowledge with other persons inside the organization. \\
4 & My company uses technology that allows employees to share knowledge with other persons outside the organization. \\
\hline
\end{tabular}

Mediating Variable Knowledge Sharing. Knowledge sharing in this study is measured using by giving and receiving knowledge by the employee. It is derived from Hooff and Weenen (2004), it assesses the degree of employee's willingness to contribute and collect the knowledge to and from each other. Giving knowledge is measured using six items adopted from Hooff and Weenen (2004) as knowledge donating, while taking knowledge is measured using eight items adopted from Hooff and Weenen (2004) as knowledge collecting, it refers to collective beliefs or behavioral routines related to the spread of learning among the employees. The measures apply a five-point Likert scale with (1) for 'strongly disagree', (2) for 'agree', (3) for 'neutral', (4) for 'agree', (5) for 'strongly agree'. The details of the items are as follows.

TABLE 3. Measurement of knowledge sharing

\begin{tabular}{ll}
\hline No. & Knowledge Sharing Items \\
\hline 1 & Giving \\
a. When I've learned something new, I tell my colleagues in my department about it. \\
b. When they've learned something new, colleagues within my department tell me about it. \\
c. Knowledge sharing with my colleagues within my department is considered normal thing. \\
d. When I've learned something new, I tell my colleagues outside of my department about it. \\
e. When they've learned something new, colleagues outside of my department tell me about it. \\
f. Knowledge sharing with my colleagues outside of my department is considered a normal thing. \\
Receiving \\
g. I share the information I have with colleagues within my department, when they ask me to. \\
h. I share my skill with colleagues within my department, when they ask me to. \\
i. Colleagues within my department tell me about what they know, when I ask them about it. \\
j. Colleagues within my department tell me what their skills are, when I ask them about it. \\
k. I share the information I have with colleagues outside of my department, when they ask me to. \\
1. I share my skills with colleagues outside of my department, when they ask me to. \\
m. Colleagues outside of my department tell me what they know, when I ask them about it. \\
n. Colleagues outside of my department tell me what their skills are, when I ask them about it. \\
\hline
\end{tabular}


Jurnal Pengurusan 58(2020)

https://doi.org/10.17576/pengurusan-2020-58-11

RESULT

REFLECTIVE MEASUREMENT MODEL

The loadings for all items exceed the recommended value of 0.40 or higher (Hair et al. 2014). AVE which is a mean variance extracted for the items loadings on a construct were all above the recommended value of 0.40 or higher (Hair et al. 2014), which means that more than one-half of the variance observed in the items were accounted for by their hypothesized factors. The AVE for this study is in the range of 0.518 to 0.800 . Composite Reliability (CR) which indicate the degree to which the latent variables can be explained by the observed variables (Tseng \& Tsai 2011 ) is in the range of 0.766 to 0.900 , which exceeds the cut off value of 0.6 (Bagozzi \& Yi 1988) and 0.90 which regarded as satisfactory (Hair et al. 2017). Thus, this study ensured the existence of convergent validity. TABLE 4 summarizes the result of the measurement model which shows that the constructs are all valid measures of their respective constructs.

TABLE 4. Descriptive statistics of all the variables used in the study

\begin{tabular}{|c|c|c|c|c|}
\hline Construct & Items & Loadings & $\mathrm{AVE}^{\mathrm{a}}$ & $\mathrm{CR}^{\mathrm{b}}$ \\
\hline \multirow[t]{4}{*}{ ICT Usage } & ICTU1 & 0.756 & 0.591 & 0.852 \\
\hline & ICTU2 & 0.778 & & \\
\hline & ICTU3 & 0.815 & & \\
\hline & ICTU4 & 0.722 & & \\
\hline \multirow[t]{5}{*}{ Knowledge Giving } & KGIV1 & 0.505 & 0.516 & 0.836 \\
\hline & KGIV2 & 0.562 & & \\
\hline & KGIV4 & 0.789 & & \\
\hline & KGIV5 & 0.803 & & \\
\hline & KGIV6 & 0.860 & & \\
\hline \multirow[t]{8}{*}{ Knowledge Receiving } & KREC1 & 0.630 & 0.587 & 0.918 \\
\hline & KREC2 & 0.828 & & \\
\hline & KREC3 & 0.858 & & \\
\hline & KREC4 & 0.564 & & \\
\hline & KREC5 & 0.779 & & \\
\hline & KREC6 & 0.859 & & \\
\hline & KREC7 & 0.822 & & \\
\hline & KREC8 & 0.738 & & \\
\hline \multirow[t]{9}{*}{ Innovative Behavior } & IB1 & 0.626 & 0.506 & 0.900 \\
\hline & IB2 & 0.671 & & \\
\hline & IB3 & 0.765 & & \\
\hline & IB4 & 0.766 & & \\
\hline & IB5 & 0.538 & & \\
\hline & IB6 & 0.519 & & \\
\hline & IB7 & 0.800 & & \\
\hline & IB8 & 0.843 & & \\
\hline & IB9 & 0.791 & & \\
\hline
\end{tabular}

TABLE 5. Tolerance and VIF values for the variables

\begin{tabular}{lcc}
\hline Variables & Tolerance Values & VIF Values \\
\hline ICT Usage & 0.454 & 2.204 \\
Knowledge Giving & 0.855 & 1.169 \\
Knowledge Receiving & 0.855 & 1.169 \\
\hline
\end{tabular}

Note: Dependent variable: Innovative behavior (IB)

The result from bootstrapping analysis showed that ICT use [ICTU: $\beta=0.067, t=0.680$ ] had non-significant relationship on giving knowledge sharing and not supported for $\mathrm{H}_{1}$. However, ICT use had positive effects on receiving knowledge sharing [ICTU: $\beta=0.498, t=4.159, \mathrm{p}<0.01$ ] . This result thus supports $\mathrm{H}_{2}$. The result from bootstrapping analysis also mention that knowledge giving [KGIV: $\beta=-0.082, t=1.631$ ] were not significant and not support the $\mathrm{H}_{3}$. While knowledge receiving [KREC: $\beta=0.218, t=3.536, \mathrm{p}<0.01$ ] had positive effects on innovative behavior, thus support $\mathrm{H}_{4}$. The results as shown in TABLE 6 .

TABLE 6. Path coefficients of ICT usage on knowledge sharing on innovative behavior 
Jurnal Pengurusan 58(2020)

https://doi.org/10.17576/pengurusan-2020-58-11

\begin{tabular}{llccccc}
\hline $\mathrm{H}$ & Relationship & Beta & Std Error & T Value & $R^{2}$ & Support \\
\hline H1 & ICTU $\rightarrow$ KGIV & 0.067 & 0.099 & 0.680 & 0.707 & No \\
H2 & ICTU $\rightarrow$ KREC & 0.498 & 0.120 & $4.159^{* *}$ & 0.482 & Yes \\
H3 & KGIV $\rightarrow$ IB & -0.082 & 0.050 & 1.631 & 0.505 & No \\
H4 & KREC $\rightarrow$ IB & 0.218 & 0.062 & $3.536^{* *}$ & 0.505 & Yes \\
\hline
\end{tabular}

Note: $\mathrm{P}<0.05^{*}, \mathrm{P}<0.01 * *$

KGIV=Knowledge Giving, KREC=Knowledge Receiving, IB=Innovative Behavior, ICTU=ICT Usage

The results of mediating path coefficients reveled that indirect effect of the relationship through knowledge giving as mediator were not significant as ICTU $(\beta=-0.006, t=0.542, \mathrm{p}<0.05)$. Therefore, $\mathrm{H}_{5}$ were not supported. However, the results of ICT usage $(\beta=0.109, t=2.585, \mathrm{p}<0.01)$ have a significant indirect effect on innovative behavior through receiving knowledge as the mediator, as the confidence intervals did not straddle a zero in between and therefore, the indirect effects were significant. Therefore, $\mathrm{H}_{6}$ were supported. The results as shown in TABLE 7.

TABLE 7. Mediating path coefficients of ICT usage on innovative behavior through knowledge sharing

\begin{tabular}{cccccccc}
\hline $\mathrm{H}$ & $\mathrm{R} /$ ship & Beta & Std Error & T value & LL & UL & Support \\
\hline $\mathrm{H}_{5}$ & ICTU $\rightarrow$ KGIV $\rightarrow$ IB & -0.006 & 0.010 & 0.542 & -0.039 & 0.006 & No \\
$\mathrm{H}_{6}$ & ICTU $\rightarrow$ KREC $\rightarrow$ IB & 0.109 & 0.042 & $2.585^{* *}$ & 0.200 & -0.035 & Yes \\
\hline
\end{tabular}

$\mathrm{P}<0.05^{*}, \mathrm{P}<0.01^{* *}$

KGIV=Knowledge Giving, KREC=Knowledge Receiving, IB=Innovative Behavior, ICTU=ICT Usage

In TABLE 8, ICT usage were not statistically significant as the effect size on giving knowledge sharing is below in the threshold based on Cohen (1988) rule of thumb. However, the results indicated that ICT use $\left(f^{2}=0.217\right)$ had medium effects on receiving knowledge sharing. The results also indicated that knowledge receiving $\left(f^{2}=0.038\right)$ had medium effects on innovative behavior. Whereas knowledge giving $\left(f^{2}=0.010\right)$ were not statistically significant have an effect size which is below in the threshold based on Cohen (1988) rule of thumb. The $R^{2}$ values of 0.505 for innovative behavior suggests that $50.5 \%$ of the variance in innovative behavior can be accounted for by receiving knowledge sharing. A $R^{2}$ value of 0.505 (exceed to 0.50 ) indicated that receiving knowledge sharing has a medium explanatory power and deliver sufficiently $R^{2}$ values respectively (Hair et al. 2014).

TABLE 8. Direct effects sizes of ICT usage on knowledge sharing and innovative behavior

\begin{tabular}{llcc}
\hline $\mathrm{H}$ & Structural Path & Effect Size $\left(\mathrm{f}^{2}\right)$ & Effect Size Rating \\
\hline $\mathrm{H}_{1}$ & ICTU $\rightarrow$ KGIV & 0.007 & No Effect \\
$\mathrm{H}_{2}$ & ICTU $\rightarrow$ KREC & 0.217 & Medium \\
$\mathrm{H}_{3}$ & KGIV $\rightarrow$ IB & 0.010 & No Effect \\
$\mathrm{H}_{4}$ & KREC $\rightarrow$ IB & 0.038 & Small \\
\hline
\end{tabular}

Note: Effect size $\left(f^{2}\right) 0.02=$ small effect; $0.15=$ medium effect, $0.35=$ large effect of the exogenous latent variable (Cohen 1988)

TABLE 9. Mediating effects sizes of ICT usage on innovative behavior through knowledge sharing

\begin{tabular}{llcc}
\hline $\mathrm{H}$ & Structural Path & Effect Size $\left(f^{2}\right)$ & Effect Size Rating \\
\hline $\mathrm{H}_{5}$ & ICTU $\rightarrow$ KGIV $\rightarrow$ IB & 0.007 & No Effect \\
$\mathrm{H}_{6}$ & ICTU $\rightarrow$ KREC $\rightarrow$ IB & 0.007 & No Effect \\
\hline
\end{tabular}

Note: Effect size $\left(f^{2}\right) 0.02=$ small effect; $0.15=$ medium effect, $0.35=$ large effect of the exogenous latent variable (Cohen 1988)

\section{ANALYSIS}

In terms of demographics, the majority of the respondents are males (59.2\%), age between $26-40$ years $(57.3 \%)$, Malaysian, educated with Bachelors' Degree (71\%), have work experience in 1-5 years, worked in their current company within 1-5 years, and majority of the are employed in American multinationals. Several remedies for common method bias have been taken during the development of the questionnaire, including having a cover letter assuring the anonymity and confidentiality responses, and using Likert scale endpoints for the independent, mediating and dependent variables. Based on the PLS-SEM analysis, the measurement model was assessed first, 


\section{Jurnal Pengurusan 58(2020) \\ https://doi.org/10.17576/pengurusan-2020-58-11}

followed by structural model. The purpose of examining the measurement model is to examine the validity and reliability of the constructs. The PLS algorithm was run to produce the outer loadings, AVE, and composite reliability of each construct. The construct validity of the constructs can be determined by examining the convergent and discriminant validity. Convergent validity is assessed by looking at the outer loadings and AVE of each construct. Discriminant validity was assessed by comparing between the squared root of the AVEs and intercorrelations of the construct. The examination of the measurement model demonstrated adequate convergent validity, discriminant validity, and reliability.

After assessing the measurement model, the structural model was examined to test the hypothesized relationships between the variables. Collinearity assessment was also examined as a part of structural models and collinearity was not found to be an issue in this study. PLS algorithm and bootstrapping were run to produce the $R^{2}$, path coefficients, $t$ values, and confidence intervals. Out of 6 hypotheses, 3 hypotheses were supported. In addition to the hypothesis testing, the direct and indirect effect size was also assessed to complement the statistical significance testing.

For the first step, the direct effect of the relationship was tested. In the relationship between the independent variables and knowledge giving, it was found that ICT use $\left(\mathrm{H}_{1}\right)$ were not significant with knowledge giving. In the relationship between independent variables with knowledge receiving, it was found that ICT use $\left(\mathrm{H}_{2}\right)$ have a significant relationship with receiving knowledge. In the relationship between the mediating variables and the dependent variable, it was found that knowledge giving $\left(\mathrm{H}_{3}\right)$ were not significant with innovative behavior, while knowledge receiving $\left(\mathrm{H}_{4}\right)$ was found to have a significant relationship with innovative behavior.

After testing the direct effects, the indirect effects were examined. In testing the mediating role of knowledge giving, it was found that the hypotheses which is ICT use $\left(\mathrm{H}_{4}\right)$ were not significant to have an indirect relationship with innovative behavior. While in testing the mediating role of knowledge receiving, it was found that ICT use $\left(\mathrm{H}_{5}\right)$ have a significant relationship with innovative behavior. In summary, $\mathrm{H}_{2}, \mathrm{H}_{4}$, and $\mathrm{H}_{6}$ were supported.

\section{DISCUSSION}

ICT usage was hypothesized to have a positive relationship with knowledge giving $\left(\mathrm{H}_{1}\right)$. However, the study found that ICT usage was not significant in the direct relationship with knowledge giving. The reason for the nonsignificant relationship in the present study is possibly due to the lack of impact ICT usage on giving knowledge activities in the organization. There is a possibility that ICT may not be the main medium of communication in the organizations thereby reducing its' importance as a tool for knowledge giving. Beside that, the respondents, who are engineers, might not feel comfortable or unable to guarantee with regard to ICT security of sharing information on the electronic medium. The result is also consistent with the findings by Syed and Rowland (2004) which mentioned that the reason for non-significant in these relationship may be related to the fact that employees used their knowledge as a source of power for personal advantage rather than organizational organizational. The engineers might feel that knowledge as their own properties which could not easily shared with other colleagues. ICT usage $\left(\mathrm{H}_{2}\right)$ was also hypothesized to have a positive and significant relationship with knowledge receiving. The results supported the hypothesis and approved that the engineers perceived that ICT is important to receive knowledge or information from colleagues or subordinates. ICT usage in the organization has always been considered as the main tools for sharing knowledge or information through the use of emails, databases, and intranet. Thus, ICT usage was useful in terms of receiving knowledge and information from their colleagues or organizational information. The result is consistent with the previous studies by Alashwal, Rahman and Beksin (2011); Antonova, Csepregi and Marchev Jr (2011); Hendriks (1999) and Lin (2007b).

In the current study, knowledge giving was hypothesized to have a positive relationship with innovative behavior $\left(\mathrm{H}_{3}\right)$. However, the results indicated that knowledge giving as non-significant in its' relationship with innovative behavior. Again,the rationale behind this result mirrors the result in $\mathrm{H}_{1}$, as the respondents may perceive that the knowledge and information that they have is exclusive and private information and could not be shared with other organizational members, as it is of more value to them and therefore they are unwilling to share it with others. While, knowledge receiving was hypothesized to have a positive relationship with innovative behavior $\left(\mathrm{H}_{4}\right)$, and the result is consistent with the hypothesis. The study found that knowledge receiving to have a significant and positive relationship with innovative behavior. These findings are consistent with previous research. The results from this study also revealed the independent variables do not have a significant indirect relationship with innovative behavior through knowledge giving as mediator $\left(\mathrm{H}_{5}\right)$. This signifies that knowledge givens were not significant as a mediator between ICT usage and innovative behavior. 
Jurnal Pengurusan 58(2020)

https://doi.org/10.17576/pengurusan-2020-58-11

\section{CONCLUSION}

This study has enriched the literature on innovative behavior by investigating the consequence of ICT usage on knowledge sharing and whether it influences innovative behavior in a manufacturing context. The result from this study may also provide valuable information to the industry as it proved that while employees willingly utilize ICT as a medium for receiving knowledge, the same could not be said for knowledge contributing or giving, as indicated by Syed and Rowland (2004) where knowledge or information is considered as a personal advantage, rather kept them to be shared. Specifically, the process of knowledge sharing to encourage innovative behavior may not achieve its' full prospect if employees consider knowledge as part of their personal domain, to be used for personal advantage instead for organizational benefit. The management or decision makers of organizations should take heed from the findings of this study to urge their organizations to implement appropriate steps to encourage knowledge sharing as empirical evidence has established that with knowledge sharing it will lead to innovative behavior among their employees. As mentioned earlier, ICT usage was significantly related to receiving knowledge. Based on the $f^{2}$ effect sizes, ICT usage has medium effects on knowledge receiving. Knowledge giving was found not significantly related to innovative behavior while knowledge receiving was found significantly related to innovative behavior. Based on the $f^{2}$ effect size, knowledge giving does not have any effects on innovative behavior. In contrast, knowledge receiving has a medium effect on innovative behavior. It implies that more attention should be paid to knowledge receiving because it has an effect in increase innovative behavior. The results suggest that the management to prioritize their actions in promoting knowledge giving because the result indicated that it has the strongest influence on innovative behavior among other variables in this study.

\section{ACKNOWLEDGMENT}

The authors wish to thank Universiti Sains Malaysia for funding this research under Research University Grant 1001/PMGT/8016008.

\section{REFERENCES}

Abdelrahman, M. \& Papamichail, K.N. 2016. The role of organisational culture on knowledge sharing by using knowledge management systems in MNCs. $22^{\text {nd }}$ Americas Conference on Information Systems, 11-14 August, San Diego.

Abdelrahman, M., Papamichail, K.N. \& Wood-Harper, T. 2016. To share or not to share: An exploratory review of knowledge management systems and knowledge sharing in multinasional corporations. UK Academy for Information System (UKAIS) 21 $1^{\text {st }}$ Annual Conference, 11-13 April, Oxford.

Agarwal, N., Brem, A. \& Dwivwdi, S. 2020. Frugal and reverse innovation for harnessing the business potential of emerging markets - The case of a Danish MNC. International Journal of Innovation Management 24(1).

Ahmad, F., Husin, H. \& Saad, M.S. 2017. The influence of individual absorptive capacity on individual knowledge acquisition of host-country national workers in foreign MNCs in Malaysia. Journal of Advanced Research in Business Marketing and Supply Chain Management 14(16): 603-618.

Alashwal, A.M., Rahman, H.A. \& Beksin, A.M. 2011. Knowledge sharing in a fragmented construction industry: On the hindsight. Scientific Research and Essays 6(7): 1530-1536.

Alavi, M. \& Leidner, D.E. 2001. Review: Knowledge management and knowledge management systems: Conceptual foundations and research issues. MIS Quarterly 25(1): 107-136.

Ali, A.A., Paris, L. \& Gunasekaran, A. 2019. Key factors influencing knowledge sharing practices and its relationship with organizational performance within the oil and gas industry. Journal of Knowledge Management 23(9): 1806-1837.

Amin, N.A.H.N., Almunawar, M.N., Hasnan, A.S. \& Besar, N.N. 2018. Preferences, benefits, and barriers of web 2.0 tools for knowledge sharing in Brunei Darussalam's Tertiary. In Education Management Strategies and Technology Fluidity in the Asian Business Sector, 253-276. Hershey: IGI Global.

Annett, M. 2019. Human resource risk and knowledge workers: Propositions for the theory and research. Journal of Management Policy and Practice 20(4): 10-20.

Antonova, A., Csepregi, A. \& Marchev Jr, A. 2011. How to extend the ICT used at organizations for transferring and sharing knowledge. IUP Journal of Knowledge Management 9(1): 37-56.

Arvanitis, S., Loukis, E.N. \& Diamantopoulou, V. 2013. Are ICT, workplace organization and human capital relevant for innovation? A comparative study based on Swiss and Greek micro data. KOF Working Papers No. 333, Zurich. 


\section{Jurnal Pengurusan 58(2020) \\ https://doi.org/10.17576/pengurusan-2020-58-11}

Bagozzi, R.P. \& Yi, Y. 1988. On the evaluation of structural equation models. Journal of the Academy of Marketing Science 16(1): 74-94.

Belle, A.R. \& Oliveira, M. 2018. The life cycle process of knowledge sharing in free software communities: Sharing profiles and motivations. Knowledge and Process Management 25(3): 143-152.

Bandura, A. 1971. Vicarious and self-reinforcement processes. In The Nature of Reinforcement, edited by R. Glaser, 228-278. New York: Academic Press.

Bandura, A. 1989. Human agency in social cognitive theory. American Psychologist 44(9): 1175-1184.

Bandura, A. 2001. Social cognitive theory: An agentic perspective. Annual Review of Psychology 52(1): 1-26.

BNM. 2019. 2020 Budget Speech. Available at https://www.bnm.gov.my/documents/budget/bs2020.pdf

Bock, G.-W., Zmud, R.W., Kim, Y.-G. \& Lee, J.-N. 2005. Behavioral intention formation in knowledge sharing: Examining the roles of extrinsic motivators, social-psychological forces, and organizational climate. MIS Quarterly 29(1): 87-111.

Chen, Huang, J.-W. \& Hsiao, Y.-C. 2010. Knowledge management and innovativeness: The role of organizational climate and structure. International Journal of Manpower 31(8): 848-870.

Cheng, M-Y., Ho, J.S-Y. \& Lau, P.M. 2009. Knowledge sharing in academic institutions: A study of Multimedia University Malaysia. Electronic Journal of Knowledge Management 7(3): 313-324.

Chmielecki, M. 2017. Knowledge Sharing in MNCs Intercultural Interactions in the Multicultural Workplace. New York: Springer.

Cohen. 1988. Some new evidence on the seriousness of crime. Criminology 26(2): 343-353.

Couper, M.P. 2017. New developments in survey data collection. Annual Review of Sociology 43: 121-145.

Danquah, M. \& Amankwah-Amoah, J. 2017. Assessing the relationships between human capital, innovation and technology adoption: Evidence from Sub-Saharan Africa. Technological Forecasting and Social Change 122: 24-33.

DonatE, M.J., de Pablo, J.D.S., Guandamilas, F. \& Gonzalez-Ramos, M.I. 2017. The role of knowledge management strategies in corporation agreements. In Strategic Information Systems and Technologies in Modern Organizations, edited by C. Howard \& K. Hargiss, 128-150. Hershey: IGI Global.

Donate, M.J. \& Guadamillas, F. 2011. Organizational factors to support knowledge management and innovation. Journal of Knowledge Management 15(6): 890-914.

Farid, H., Hakimian, F. \& Ismail, M.N. 2017. How Malaysian managers persuade employees' innovative behaviour? Int. J. Management and Enterprise Development 16(4): 291-307.

Goh, S.-K., Jayaraman, K., Mostafiz, M.I. \& Leow, Y.M. 2020. The effect of organisational climate on employees creative performance through knowledge sharing behavior. Electronic Journal of Knowledge Management 18(1): 1-14.

Groth, K. \& Bowers, J. 2001. On finding things out: Situating organisational knowledge in CSCW. Paper presented at the ECSCW 2001.

Hachicha, Z.S. \& Mezghani, K. 2018. Understanding intentions to switch toward cloud computing at firm's level: A multiple case study in Tunisia. Journal of Global Information Management 26(1): 136-165.

Hair, J.F., Hult, G.T.M., Ringle, C.M. \& Sarstedt, M. 2014. A Primer on Partial Least Squares Structural Equation Modelling (PLS-SEM). Los Angeles: SAGE Publication, Inc.

Hair Jr, J.F., Sarstedt, M., Ringle, C.M. \& Gudergan, S.P. 2017. Advanced Issues in Partial Least Squares Structural Equation Modeling. Thousand Oaks, CA: Sage Publications.

Haythornthwaite, C. \& Wellman, B. 1998. Work, friendship, and media use for information exchange in a networked organization. Journal of the American Society for Information Science 49(12): 1101-1114.

Hendriks, P.H. 1999. Why share knowledge? The influence of ICT on the motivation for knowledge sharing. Knowledge and Process Management 6(2): 91-100.

Hooff, B.V.D., Elving, W., Meeuwsen, J.M. \& Dumoulin, C. 2003. Knowledge sharing in knowledge communities. In Communities and Technologies, edited by M. Huysman, E. Wenger \& V. Wulf, 119-141. Neitherlands: Kluwer, B.V.

Hooff, B.V.D. \& Ridder, A. 2004. Knowledge sharing in context: the influence of organizational commitment, communication climate and CMC use on knowledge sharing. Journal of Knowledge Management 8(6): 117127.

Hooff, B.V.D., Ridder, J.d. \& Aukema, E. 2004. The eagerness to share: Knowledge sharing, ICT and social capital. Working Paper.

Hooff, B.V.D. \& Weenen, F.D.L.V. 2004. Committed to share: Commitment and CMC use as antecedents of knowledge sharing. Knowledge and Process Management 11(1): 13-24. 


\section{Jurnal Pengurusan 58(2020) \\ https://doi.org/10.17576/pengurusan-2020-58-11}

Hussein, A.T.T., Singh, S.K., Farouk, S. \& Sohal, A.s. 2016. Knowledge sharing enables, process and firm innovation capability. Journal of Workplace Learning 28(8): 484-495.

Ibrahim, S.K. \& Jebur, Z.T. 2019. Impact of information communication technology on business firms. International Journal of Science and Engineering Applications 8(2): 53-56.

Janssen, O. 2000. Job demands, perceptions of effort $\square$ reward fairness and innovative work behaviour. Journal of Occupational and Organizational Psychology 73(3): 287-302.

Jasimuddin, S.M., Li, J. \& Perdikis, N. 2019. An empirical study of the role of knowledge characteristics and tools on knowledge transfer in China-based multinationals. Journal of Global Information Management 27(1): 165195.

Kaabi, A.A., Elanain, H.A. \& Ajmal M.M. 2018. HRM practices and innovation performance with the mediating effect of knowledge sharing: Empirical evidence from Emirati ICT companies. International Journal of Innovation and Learning 24(1): 41-61.

Karkoulian, S., Harake, N.A. \& Messarra, L.C. 2010. Correlates of organizational commitment and knowledge sharing via emotional intelligence: An empirical investigation. The Business Review, Cambridge, Hollywood 15(1): 89-89.

Khanam, L. Mahfuz, M.A., Yuanjian, Q. \& Alam, M.Z. 2017. Exploring the role of ICT usage and collaborative climate on explicit knowledge sharing behavior of Chinese university students. MIST International Journal of Science and Technology 5(1): 73-84.

Khawaja, K.F. 2017. Why should I trust ICT? An empirical study examining teachers and students usage of ICT for knowledge sharing and seeking. Paper presented at the International Conference on Advances in Business, Management and Law (ICABML).

Kim, Y.-H., Choe, E.K., Lee, B. \& Seo, J. 2019. Understanding personal productivity: how knowledge workers define, evaluate, and reflect on their productivity. Paper presented at Proceedings of the $2019 \mathrm{CHI}$ Conference on Human Factors in Computing Systems.

Kucharska, W. \& Bedford, D.A. 2019. Knowledge sharing and organizational culture dimensions: does job satisfaction matter? Electronic Journal of Knowledge Management 17(1): 1-18.

Kuncoro, W. \& Suriani, W.O. 2017. Achieving sustainable competitive advantage through product innovation and market driving. Asia Pacific Management Review 23(3): 186-193.

Lin, H.-F. 2007a. Effects of extrinsic and intrinsic motivation on employee knowledge sharing intentions. Journal of Information Science 33(2):135-149.

Lin, H.-F. 2007b. Knowledge sharing and firm innovation capability: An empirical study. International Journal of manpower 28(3/4): 315-332.

Lind, C.H., Kang, O., Ljung, A. \& Forsgren, M. 2018. MNC involvement in social innovations: The issue of knowledge, networks and power. Critical Perspectives on International Business 16(1): 79-99.

Madhavaram, S., Matos, V., Blake, B.A. \& Appan, R. 2017. ICTs in the context of disaster management, stakeholders, and implications. Journal of Information, Communication and Ethics in Society 15(1): 32-52.

Maimone, F. 2018. An integrated approach to facilitate knowledge sharing among and beyond cultural barriers, using social media. In Intercultural Knowledge Sharing in MNCs, edited by F. Maimone, 157-189. Springer.

Malhotra, Y. 2000. Knowledge management for e-business performance: advancing information strategy to "internet time". Information Strategy: The Executive's Journal 16(4): 5-16.

Michailova, S. \& Minbaeva, D. B. 2012. Organizational values and knowledge sharing in multinational corporations: The Danisco case. International Business Review 21(1): 59-70.

Mura, M., Lettieri, E., Radaelli, G. \& Spiller, N. 2013. Promoting professionals' innovative behaviour through knowledge sharing: the moderating role of social capital. Journal of Knowledge Management 17(4): 527-544.

Nguyen, T., Tran, N., Doan, X. \& Nguyen, H. 2020. The impact of knowledge sharing on innovative work behavior of Vietnam telecommunications enterprises employees. Management Science Letters 10(1): 53-62.

Obeidat, B.Y., Al-Suradi, M.M. \& Tarhini, A. 2016. The impact of knowledge management on innovation. Management Research Review 39(10): 1214-1238.

Oldenkamp, J.H. 2001. Limitations of managing knowledge sharing. Paper presented at the Proceedings of the Second European Conference on Knowledge Management, Bled, Slovenia.

Panir, M.J.H., Xiolon, X. \& Zijun, M. 2019. Integration of ICT with knowledge management to foster digital innovation: the case of Bangladesh public sector. International Journal of Managing Public Sector Information and Communication Technologies 9(4): 1-16.

Phung, D., Hawryszkiewycz, I. \& Binsawad, M. 2017. Exploring how environmental and personal factors influence knowledge sharing behavior leads to innovative work behavior in Vietnamese higher education institution. 


\section{Jurnal Pengurusan 58(2020) \\ https://doi.org/10.17576/pengurusan-2020-58-11}

Information Systems Development: Advances in Methods, Tools and Management (ISD2017 Proceedings), 110.

Podrug, N., Filipovic, D. \& Kovac, M. 2017. Knowledge sharing and firm innovation capability in Croation ICT companies. International Journal of Manpower 38(4): 632-644.

Razmerita, L., Kirchner, K. \& Nielsen, P. 2016. What factors influence knowledge sharing in organizations? A social dilemma perspective of social media communication. Journal of Knowledge Management 20(6): 12251246.

Singh, J.B., Chandwani. R. \& Kumar, M. 2018. Factors affecting web 2.0 adoption: Exploring the knowledge sharing and knowledge seeking aspects in health care professionals. Journal of Knowledge Management 22(1): 21-43.

Stajkovic, A.D., Bandura, A., Locke, E.A., Lee. D. \& Sergent, K. 2018. Test of three conceptual models of influence of the big five personality traits and self-efficacy on academic performance: A meta-analytic path-analysis. Personality and Individual Differences 120: 238-245.

Stephens, K.K. 2007. The successive use of information and communication technologies at work. Communication Theory 17(4): 486-507.

Stephens, K.K., Sørnes, J.O., Rice, R.E., Browning, L.D. \& Sætre, A.S. 2008. Discrete, sequential, and follow-up use of information and communication technology by experienced ICT users. Management Communication Quarterly 22(2): 197-231.

Suppiah, V. \& Sandhu, M.S. 2011. Organisational culture's influence on tacit knowledge-sharing behaviour. Journal of Knowledge Management 15(3): 462-477.

Syed, O.S.S.-I. \& Rowland, F. 2004. Knowledge management in a public organization: A study on the relationship between organizational elements and the performance of knowledge transfer. Journal of Knowledge Management 8(2): 95-111.

Taylor, W.A. \& Wright, G.H. 2004. Organizational readiness for successful knowledge sharing: Challenges for public sector managers. Information Resources Management Journal 17(2): 22-37.

Tohidinia, Z. \& Mosakhani, M. 2010. Knowledge sharing behaviour and its predictors. Industrial Management \& Data Systems 110(4): 611-631.

Tseng, C.-J. \& Tsai, S.-C. 2011. Effect of consumer environmental attitude on green consumption decision-making. Pakistan Journal of Statistics 27(5): 699-708.

Usman, M., Ahmad, M.I. \& Burgoyne, J. 2019. Individual and organizational learning from inter-firm knowledge sharing: A framework integrating inter-firm and intra-firm knowledge sharing and learning. Canadian Journal of Administrative Sciences 36(4): 484-497.

Wang, \& Noe, R.A. 2010. Knowledge sharing: A review and directions for future research. Human Resource Management Review 20(2): 115-131.

Wasko, M.M. \& Faraj, S. 2005. Why should I share? Examining social capital and knowledge contribution in electronic networks of practice. MIS Quarterly 29(1): 35-57.

Yadav, M., Choudhary, S. \& Jain, S. 2019. Transformational leadership and knowledge sharing behavior in freelancers: A moderated mediation model with employee engagement and social support. Journal of Global Operations and Strategic Sourcing 12(2): 202-224.

Yuan., Y.C., Zhao, X., Liao, Q. \& Chi, C. 2013. The use of different information and communication technologies to support knowledge sharing in organizations: From e $\square$ mail to micro $\square$ blogging. Journal of the American Society for Information Science and Technology 64(8): 1659-1670.

Yu, C., Yu-Fang, T. \& Yu-Cheh, C. 2013. Knowledge sharing, organizational climate, and innovative behavior: A cross-level analysis of effects. Social Behavior and Personality: An International Journal 41(1): 143-156.

Yu, L., Li, H., Wang, Z. \& Duan, Y. 2019. Technology imports and self-innovation in the context of innovation quality. International Journal of Production Economics 214: 22-52.

Zhou, W., Velamuri, V.K., Dauth, T. 2017. Changing innovation roles of foreign subsidiaries from the manufacturing industry in China. International Journal of Innovation Management 21(1): 1-32.

Hazril Izwar Ibrahim

School of Management

Universiti Sains Malaysia

11800 USM Penang, MALAYSIA.

E-Mail: hazrilizwar@usm.my 
Jurnal Pengurusan 58(2020)

https://doi.org/10.17576/pengurusan-2020-58-11

Wan Maisara Wan Mohamad (corresponding author)

School of Management

Universiti Sains Malaysia

11800 USM Penang, MALAYSIA

E-Mail:wanmaisara@gmail.com

Khairul Anuar Mohammad Shah

School of Management

Universiti Sains Malaysia

11800 USM Penang, MALAYSIA

E-Mail: khairulms@usm.my 